\title{
The Application of Indian Tradition of Ahimsa in Modern Politics: Conceptual Analysis on the Foundations of Hard Power and Immorality in National and International Politics
}

\author{
Sisay Assemrie Temesgen ${ }^{1} \& \operatorname{Irshad}_{\text {Ahmed }}{ }^{1}$ \\ ${ }^{1}$ College of Social Science and Humanities, Madawalabu University, Bale Robe, Ethiopia \\ Correspondence: Sisay Assemrie Temesgen, College of Social Science and Humanities, Madawalabu University, \\ Bale Robe, Ethiopia. Tel: 25-193-171-4710. E-mail: sisay.assemrie@gmail.com
}

Received: August 26, 2016

Accepted: September 1, 2016

Online Published: April 19, 2017

doi: $10.5539 /$ res.v9n2p158

URL: http://doi.org/10.5539/res.v9n2p158

\begin{abstract}
The Indian tradition, Ahimsa which instils absolute non-violence, equality, universal love and oneness of all human beings is believed to have a guiding role in the conduct of national and international politics. But, the practical contribution of Ahimsa has been insignificant and questionable both in modern national and international politics. Historically contingent truths about the natures of modern national politics have witnessed; values, norms and laws of states are mainly executed by the use of hard power and immoral instruments as conditions dictate. Monopoly of coercive apparatus and conditional immorality are proved to be the core essences of modern states. International relation is also characterized by the logic of political realism which gives priority to state power and national interest than Ahimsa's universal principles of love and oneness of all human beings. In this article, by using analytic approach, an effort is made to critically analyze concepts to expound the existence of basic contradictions of the moral principles and values of Ahimsa with the basic natures and purposes of the politics of modern sates and international relations.
\end{abstract}

Keywords: Ahimsa, power, morality, politics

\section{Introduction}

Ahimsa is a very old, broad and base of Indian moral philosophy. It is not only a moral philosophy but also it has been one of the major ethical principles in the daily life of Indian people, starting from ancient Indian civilization to the present (Sharma, 1965, p. 325). Ahimsa, which is literally conceived as non-force, or non-violence is a doctrine common to the three Indian major religions; Jainism, Hinduism, and Buddhism (Bishop, 1978, p. 57).

Conventionally, it is conceived as a means of handling social relations and solving conflicts without the use of physical violence and other immoral means. But, the tradition of Ahimsa has been used in a much wider sense than only the absence of violence and moral perfection. It implies not causing any kind of hurt or making harm to anybody both physically and mentally by using physical force, language or other means (Prana, 2003). It includes not only the prohibition of using of violent action but also abstaining from conceiving violence in thought. Thus, it restricts using physical violence and immoral behaviors as well as freedom of thought and speech (Bishop, 1978, p. 58).

In the tradition of Ahimsa, spiritual awakening and development through inner practice is considered as the highest manifestation of humanity and absolutely necessary for followers to attain moral progress, and self-actualization or godliness. This can be achieved by exercising the moral principles of Ahimsa (Note 1) in daily material life and conducting deep pray to God (Prana, 2003, p. 2; Bhaneja, 2007, pp. 222-223).

In addition to its perceived role of spiritual development and self-realization of individual's soul, Ahimsa which advocates the principles of humanism and universal love is considered as a means of actualizing absolute peace, justice, equality, morality and unity of human beings in the arena of national and international politics. Particularly, Gandhi (during and after independence) had practically attempted to lead Indian politics and international relations by the moral principles of Ahimsa. Though, he failed to implement even at the cost of his life (Sharma, 1965, pp. 336-350; Bhaneja, 2007, p. 221). In "All Men are Brothers; Life and Thoughts of M. Gandhi (Note 2) as Told in His Own Words", Krishna (1969, p. 122) cited: 
There is no limit to extending our services to our neighbors across State, [which] made frontiers. God never made those frontiers. My goal is friendship with the whole world and I can combine the greatest love with the greatest opposition to wrong. For me patriotism is the same as humanity. I am patriotic because I am human and humane. It is not exclusive, I will not hurt England or Germany to serve India. Imperialism has no place in my scheme of life. The law of a patriot is not different from that of the patriarch. And a patriot is so much the less a patriot if he is a lukewarm humanitarian. There is no conflict between private and political law.

In reality, principles and moral attributes of Ahimsa has been insignificant and questionable in the conduct of national and international politics of modern states. Thus, this article is designed to analyze the role of Ahimsa in the conduct of national and international politics. (1) by critically analyzing the real natures of national and international politics of modern state, I made an effort to illustrate the contradiction of moral values of Ahimsa (Note 3) with the very existence of modern states and logical principle of international relations. (2) International laws and organizations are instruments of national interest; they are the reflections or extensions of modern states. In this case, I tried to elaborate the contradiction of values of Ahimsa with the core natures and purposes of international laws and organizations.

Only preliminary researches are done on the contradiction of moral values and principles of Ahimsa with national and international politics of modern states. Particularly, as much as my observation is concerned, no research is done by using analytical research approach to critically analyze concepts to prove the existence of basic contradictions between moral principles of Ahimsa and real natures and purposes of national and international politics of modern states.

For this objective, I employed analytic research approach to acquire an in-depth conceptual understanding about contradiction of moral principles of Ahimsa with the very existence of modern states, logical principles of international relations and the core natures and purposes of international laws and organizations. Thus, this article is written by studying a wide array of relevant sources, both published and unpublished. Mainly, it is based on secondary data sources such as books, seminar papers, commentaries, periodicals, dissertations, and journal articles.

\section{The Concept of Ahimsa in Indian Tradition}

The tradition of Ahimsa is a very old, complex and basis of Indian moral philosophy. It is not only a moral philosophy but it has been also one of the major ethical principles in the religious and secular life of Indian people (Sharma, 1965, p. 325).

In the traditional religions of India, foundations of Hindu religion; Lord Krishna (Note 4), and Sanatana Dharma (Note 5) had preached their believers to accept Ahimsa as the principle of non-injury of life and the only way to merge into the absolute truth or to be a God kind creature (Prana, 2003, pp. 1-3). To cultivate the moral values of Ahimsa within the heart and mind set of his followers, Prophet Sri Chaitanya, in the 5th century, had delivered his message:

We have to be more humble than grass and more patient than trees, we have to give respect to each and every living being and we always have to remember God. These are the supreme qualities of human nature. The one who has all these qualities will be able to attain the principle of absolute non-violence (Ibid, p. 2).

The dominant religions of India; Jainism, Hinduism, Buddhism and Christianity are also based on the religious teaching of "not causing injure to any living being". The teaching of each religion preached Ahimsa to be the moral principle of human life to preserve and nurture all creations (Ibid; Bishop, 1978, pp. 57-63). Particularly, Buddhism prohibits all forms of violence and destruction against any kinds of creatures (Kovan, 2009). To establish a non-violent society that never cause injury to each and every human being, Lord Buddha (Note 6) had preached his followers:

Do not look at others' mistake, what others have done and not done, but rather look at what you yourself have done or failed to do... place yourself in others' position and refrain from beating and killing. By friendship you conquer the angry, by goodness you conquer the evil, and by generosity you can conquer the miser and the liar by truthfulness. In battle, anyone [may] conquer thousands and thousands, still the greatest victor is the one who conquers himself (Prana, 2003, p. 4).

From the above quotation, we can deduce that Buddhism as a religion consists of non-violent moral values such as love, non-injury, honesty, fellow-feeling, patience, unity, respect, etc. Irrespective of any circumstances, even 
at the cost of their life, followers have the duty to be free from any kind of violent and immoral thought and activities.

In Indian traditions, both in ancient and modern, Ahimsa is defined as the means of God realization or getting nearer to truth, who is the source of human spirit (Sharma, 1965, p. 326). In this definition, Ahimsa is conceived as a way of men's realization of God, by possessing his traits.

Ahimsa is also defined as a means of eliminating disharmony that exists within the social and natural environment. It is considered as a movement of eliminating violence in all aspects of social life and means of treating the entire nature with respect and civility. It is to develop a harmonious interaction among human beings and between human beings and their natural environment (Kurtz \& Kurtz, 2005, pp. 350-352). This definition implies the devotion of followers of Ahimsa for the creation of social structures that promote universal love, unity, justice, equality, self-actualization of every person and preservation of nature. The prominent advocator of Ahimsa, Gandhi (1948, p. 85) wrote:

Just as one must learn the art of killing in the training for violence, so one must learn the art of dying in the training for non-violence. Violence does not mean emancipation from fear, but discovering the means of combating the cause of fear. Non-violence, on the other hand, has no cause for fear. The votary of non-violence has to cultivate the capacity for sacrifice of the highest type in order to be free from fear. He rucks not if he should lose his land, his wealth, his life. He who has not overcome all fear cannot practice Ahimsa to perfection.

For a specific purpose, Ahimsa is also defined as an instrument of realizing peaceful co-existence, justice, stability, safety, friendship, equality and freedom in the arena of national and international politics. This goal is assumed to be achieved through conducting open deliberations, dialogues, debates, persuasions and non-cooperation with evil actors in the arena of national and international politics (Sharma, 1965, p. 336; Bhaneja, 2007, pp. 220-225). This definition provides a specific meaning of Ahimsa. It emphasis on the contribution of Ahimsa for the realization of political goals, both at domestic and international level. The general purpose of this article is to critically evaluate the applicability of this definition on the real ground.

The comprehensive definition of Ahimsa, which includes the above definitions has negative and positive elements. The negative element of Ahimsa is defined as refraining from causing any kind of harm to anybody both physically and mentally, or not making any pain or injury to any kinds of creatures by any possible way (Sihra, 2006, pp. 42-43; Prana, 2003, pp. 1-7; Bhaneja, 2007, p. 221).

Insisting the superior moral characters of Ahimsa, followers must be civil, patient, just, and under no circumstance counter violence with violence (Ibid.). By upholding the moral superiority of negative elements of Ahimsa or refraining from causing injury, it is believed to bring change in the heart of the opponents or wrong doers.

In its positive element, Ahimsa connotes followers' mental consciousness of oneness, love, charity, compassion, eternity of the soul and omnipresence of truth. What is essentially important in this element of Ahimsa is, followers must extend positive moral treatments to other creatures (Ibid). Sihra (2006, p. 43) explained:

...It is not because apart from the ocean [community], it [individuality] has no existence. It is because the ocean has no existence, if the drop has not, i.e., has no individuality. They are beautifully interdependent... and if this is true of the physical, how much more so of the spiritual world. The relationship of individuality and community is not one that is mutually exclusive, nor does it demand a sacrifice of oneself. It demands engagement of oneself with oneself and the other.

The basic difference between negative and positive elements of Ahimsa is, in the negative element of Ahimsa, practitioners are not expected to forward love and charity to other creatures. Because, love and charity can't be extended only by refraining from injuring other creatures.

\section{Hard Power and Conditional Immorality as Basic Essences of Modern States}

The role of Ahimsa which advocates the principle of absolute morality and non-violence is questionable and contradictory with the politics of modern states. There are many factors that cause insignificance and contradiction of the principles of Ahimsa with the politics of modern states. For the purpose of this study, analysis is made to show the contradiction of principles of Ahimsa with the fundamental definition and functions of modern states, and relative and dynamic nature of modern politics.

From the beginning, modern states are basically established to regulate the competitive, conflictual and complex nature of human beings. Whether they are strong or weak, modern states are defined by their monopoly of 
political power and legitimate use of force (Michael, 2011, pp. xv-vi; Marcel, 2011, pp. 20-30). Monopoly of coercive apparatus "arises from divisive political conflict and the need to settle the problem of order" (Rawls, 2001, p. 9). As Larmore (2012, p. 3) analyzed, the very origin of state is:
People disagree and their disagreements extend from their material and status interests to their very ideas of the right and the good, so that society is possible only through the establishment of authoritative rules, binding on all and backed by the threat or use of force... For political philosophy, their validity has to be judged by how well they handle the distinctive problems of political life, which are conflict, disagreement, power, and authority. On this view, the very heart of justice lies in determining what rules may be legitimately imposed on the members of society.

Modern states are established to employ coercive power for the sake of actualizing peace, order, security, justice, development, and civilization. The maintenance of morally right social and institutional values, and the accommodation of divergent social, political, cultural and economic interests are dependent on states' monopoly and effective use of coercive power (Ibid.). Chen (2010, p. 12) consolidated:

\begin{abstract}
... a modern state is a monopolizer of legitimate violence [force] and taxation within a given territory. It not only possesses the administrative structure of bureaucratization and political centralization but also dictates the symbolic and practical templates of "civility" "society" and “civilization”. The state's monopolization of power renders possible internal pacification and the modernization processes of commercialization and urbanization.
\end{abstract}

As Chen observed, the transition from state of nature, anarchy and repressive autocracy to the rule of democracy and morality always involves explicit use of the coercive apparatus and immoral appliances. History witnessed, one of the most prominent factors for the transition of Europe and North America from the state of civil-war and disharmony to democratization and human development had been the institutionalization and robustness of states' coercive apparatus (Michael, 2011; Marcel, 2011).

On the reverse, lack of government capacity to enforce rules and formally adopted international agreements through strengthening coercive power of government has significant risk for the survival and legitimacy of states, and the existence of morally right social and institutional values (Rotberg, 2003; William, 2001; Kassner, 2007). In this case, underdeveloped nations and states that are in state of conflicts and civil wars are characterized by their weakness of monopoly and effective use of coercive force. In such states, the existence of morality, social values, humanity, freedom and development (mental and material) has been too scarce and unattainable.

From the above arguments, we can infer that the principle of Ahimsa which advocates the use of violent force as absolute evil is fundamentally in contradiction with the very foundation of modern states. The basic argument is, men are naturally problematic and conflictual. When there is no government that monopolizes and employs physical force and violence to regulate their relationships; fundamental values of Ahimsa such as tolerance, love, kindness, forgiveness, humbleness, patience, equality, civility, humanity, unity, brotherhood, justice, and development cannot be attained. Thus, states' use of physical force and violence have a significant role not only for the prevalence of morality and social values but also for the very existence of human race.

On the other hand, unlike the politics of antiquity and medieval kingdoms; the role of morality is secondary in the politics of modern states (Lipson, 2005, p. 2; Strauss, 1959, pp. 36-37). Unlike to modern politics; in ancient and medieval periods, people more or less agree on what personal traits are positive. As a result, moral values had overwhelming approval or disapproval in governmental institutions.

In the politics of antiquity, kings and public figures had established their empires and authority by their personal charisma, just-mindedness, charity, honesty, fairness and other socially accepted norms and values; thus morality had played an essential role (Ibid.). Due to the main goal of political life had been actualizing virtue and order in the empires of antiquity, monopolizing the diversity of moral outlooks and inculcating virtue to the society had been the conducive system of rule (Lipson, 2005, pp. 2-3). Strauss (1959, p. 36) stated "more generally, the classics rejected democracy because they thought that the aim of human life is not freedom, but virtue. Freedom as a goal is ambiguous, because it is freedom for evil as well as for good".

In the politics of medieval kingdoms; social values, institutional norms, the organization of just states, and the authority of wise feudal lords and kings had established by the "consent of the heaven" or based on religious principles of conduct (Lipson, 2005, pp. 2-9). As a result morality had played a significant and primary role in national politics.

In modern politics, due to relativity or pluralism of ideas, debates, values and judgments, people strongly disagree on what should be the social norms or moral principles. "Social morality is a reflection of individual's 
standard of bad and good, benefits and demands while each individuals trying vehemently to impose their own norms on the society as a whole" (Ibid.). Principles of morality are relative to each individual. Rawls (2001, p. 10) elaborated:
I believe that a democratic society is not and cannot be a community, where by a community I mean a body of persons united in affirming the same comprehensive, or partially comprehensive, doctrine. The fact of reasonable pluralism which characterizes a free society with free institution makes this impossible. This is the fact of profound and irreconcilable differences in citizens' reasonable comprehensive religious and political conception of the world, in the view of moral and aesthetic values to be sought in human lives.

Most of the time, disagreement or confrontational divisiveness of morality is originated from natural and artificial factors such as difference in terms of class, educational backgrounds, and level of understanding, demography, culture, ideological, and racial grounds (Ibid.; Miller, 1984, pp. 355-357; Green, 1998, pp. 440-442). To the eternity of relative and dynamic nature of modern society and moral determinism, Voltaire echoed:

Everything happens through immutable laws; everything is necessary... "there are" some persons say, "some events which are necessary and others which are not". It would be very comic that one part of the world was arranged, and the other were not; ... if one looks closely at it, one see that the doctrine contrary to that of destiny is absurd, but there are many people destined to reason badly; others not to reason at all, others to persecute those who reason. I necessarily have the passion for writing this, and you the passion for condemning me; both of us are equally the toy of destiny.Your nature is to do harm, mine is to love truth, and to make it public in spite of you (Quoted in Edwards, 1958, p. 297).

Taking into account the reality of diversity of human understanding, pluralism is valued as the main principle of democratic system in modern politics. Hence, modern politics is characterized by the prevalence of more than one party or multi-party system in one country. In such political system, parties have various positions in a given political order. They can shift their positions by compromising and forming alliances or getting into conflict when there are the real or perceived irreconcilable positions (Lipson, 2005, pp. 2-6).

Because of this dynamics nature of modern politics, "what was good yesterday may be totally useless today" (Ibid., p. 5). As a result, the moral quality of leaders has to be flexible that changes with the character of political life and facts of history. The founder of modern political philosophy, Machiavelli (1532, pp. 112-113) mentioned moral attributes of a successful leader:

one is reputed generous, one rapacious; one cruel, one compassionate; one faithless, another faithful; one effeminate and cowardly, another bold and brave; one affable, another haughty; one lascivious, another chaste; one sincere, another cunning; one hard, another easy; one grave, another frivolous; one religious, another unbelieving, and the like. And I know that everyone will confess that it would be most praiseworthy in a [leader] to exhibit all the above qualities that are considered good; but because they can neither be entirely possessed nor observed, for human conditions do not permit it, it is necessary for him to be sufficiently prudent that he may know how to avoid the reproach of those vices which would lose him his state; and also to keep himself, if it be possible, from those which would not lose him it; but this not being possible, he may with less hesitation abandon himself to them.

In addition, in the politics of modern states, political debates and competitions are on economic arguments, socio-cultural policies, and other logical reasons of state. Morality is only considered as a tool for winning the electorates approval and augmenting political power of leaders (Lipson, 2005, pp. 5-8; Strauss, 1959, p. 42). Modern politics is governed by objective laws or logical reasons of the state that have their roots in dialectical law of nature (Note 7); not by the abstract principle of the tradition of Ahimsa like justice, oneness of human soul and universal love. As Cozette (2008, pp. 34-35) pointed, "a reputation of a dreamer, an unrestrained adventurer, magicians and prophets would not win anyone's support while political realism has been considered as an important virtue for a state leader". In this context, the Indian tradition of Ahimsa is with full of dreams, adventurism and mysticism.

\section{The Tradition of Ahimsa Vs Logical Principles of International Relations}

The tradition of Ahimsa teaches the possibility of economic and political non-cooperation and isolation of India from morally deteriorated external world, particularly from the capitalist West. On the other aspect, Ahimsa 
urges follower to struggle for the actualization of universal love, truth, equality and humanism on the earth. In “All Men are Brothers; Life and Thoughts of Mahatma Gandhi as Told in His Own Words”, Krishna (1969, pp. 118-119) stated:

There is not a single virtue which aims at, or is content with, the welfare of the individual alone. Conversely, there is not a single moral offence which does not, directly or indirectly, affect many others besides the actual offender. Hence, whether an individual is good or bad is not merely his own concern, but really the concern of the whole community, nay, of the whole world. It is impossible for one to be an internationalist without being a nationalist. Internationalism is possible only when nationalism becomes a fact, i.e., when peoples belonging to different countries have organized themselves and are able to act as one man. It is not nationalism that is evil, it is the narrowness, selfishness, exclusiveness which is the bane of modern nations which is evil. Each wants to profit at the expense of, and rise on the ruin of the other.

As Morgenthau (1948, p. 13) remarked "international politics, like all politics, is a struggle for power. Whatever the ultimate aims of international politics, power is always the immediate aim". Thus, unlike the principles of Ahimsa, the fundamental nature of international politics is characterized by the existence of inevitable and continual competition for national interest, collision and violence among sovereign states. History of international relations witnessed, though international relation is not characterized by a constant state of war, it is fashioned by a state of relentless security competition with the possibility of war in the background (Donnelly, 2000, p. 131; Kortunov, 2006, pp. 8-9).

In this context, political realists are skeptical about the relevance of morality and humanitarianism in the arena of international politics. Kassner (2007, p. 30) observed, "Such skeptical arguments rest on the proposition that morality doesn't apply to states or the international community, or at least not in the same way it does to individuals". Based on empirical analysis of history of international relations, there are many factors for the insignificance and questionability of Ahimsa's principle of absolute morality and humanitarianism in the conduct of international relationships. Some of the most fundamental factors are the principle of national interest and anarchic nature of international system.

The fundamental blunder of Indian tradition of Ahimsa is misconception on the real nature of man. In this tradition, it is assumed that man is by nature absolutely good and non-violent. It is accepted that men are inherently free from all forms of negative emotions and can develop the virtues of absolute truthfulness, love, humanity, justice, and equal mentality through practicing principles of Ahimsa in daily material life.

In reality, men are not inherently free from greedy, aggressive, selfish, subjective, nasty, complex and unpredictable characters. Man cannot be perfected by any means; by culture, government institutions and laws. This nature is a root cause for the prevalence of competition, deception, violence and war to be inevitable and continual throughout the history of international relations (Donnelly, 2000, pp. 107-120; Kortunov, 2006, pp. 10-15). In this regard, one of the founders of political realism, Hobbes (1651, p. 89) expounded the condition of a man making a journey:

[He] arms himself, and seeks to go well accompanied; when going to sleep, he locks his doors; when even in his house he locks his chests; and this when he knows there be laws, and public officers, armed, to revenge all injuries [which] shall be done [on] him; what opinion he has of his fellow subjects, when he rides armed; of his fellow citizens, when he locks his doors; and of his children, and servants, when he locks his chests. Does he not there as much accuse mankind by his actions, as I do by my words? But neither of us accuses man's nature in it.

The logical implication is, man inherently possesses immoral behaviors that cause fear, violence, and war to be inevitable in international politics. Even though men are politically collectivized and organized, their natural behaviors could not be absolutely perfected. If there is no moral perfection, human beings cannot be free from evil thoughts and actions, though they are living under political authority.

In contradiction to the principle of Ahimsa, states are also rational actors, which is guided by the principle of national interests and priorities. Realistically, national interests of states are defined in terms of securing survival, security, power, ideological beliefs, and material gains; not in terms of universal principles of love, humanity, equality and justice (Slaughter, 2011, p. 28; Donnelly, 2000, pp. 7-8; Holsti, 1985, p. 5). In “The Six Principles of Political Realism", Morgenthau (1948, pp. 5-6) contended the vitality of power and national interest over the principles and values of Ahimsa: 
Interest defined as power is an objective category which is universally valid, but whose meaning can change... Universal moral principles cannot be applied to the actions of states in the abstract; the circumstances of time and place must be considered. The state must place its survival above all other moral goods. Thus, prudence "the weighing of the consequences of alternative political actions" is the "supreme virtue in politics". ... Actions are judged by their consequences. The moral laws that govern the universe are distinct for the morals of any one nation.

In international relations, states are not concerned with moral justifications beyond securing their national privileges. Depending on their own relative power, they get in to cooperation primarily calculating the amount of national interest they can gain from the relationships. This co-operation can be accepted and sustained if and only if states are perceiving or securing their national interests (Mearsheimer, 1995, p. 9; Slaughter, 2011, p. 2; Holsti, 2005, pp. 11-12). In case of bi-lateral free trade agreement, the logical assumption is, "If both countries lower their tariffs, they will trade more and each will become prosperous, but neither wants to lower barriers unless it can be sure the other will too" (Mearsheimer, 1995, p. 9).

Because of the scarcity of immediate needs and the prevalence of ideological, cultural and other differences among sovereign states; the logic of national interest is characterized by disagreement, competition and violence (Donnelly, 2000, pp. 107-120; Kortunov, 2006, pp. 8-13; Waltz, 1988, pp. 616-617). Scarcity and diversity have been the most common and accepted causes of conflicts throughout the development of international relationships even by liberal international theory. Particularly, when there is scarcity of resources, even if we assume that men are naturally good, competition and struggle for scarce resources certainly causes violence and immorality to be unavoidable among sovereign states (Waltz, 1988, p. 616). He argued:

When there is competition for scarce goods and no one to serve as arbiter. A struggle for power will ensue among the competitors and that consequently the struggle for power can be explained without reference to the evil born in men. The struggle for power arises simply because men want things, not because of the evil in their desires (Ibid.).

In the reality of diversity and scarcity, by securing national interest; states are concerned with having legitimate government; not with the issue of morality (Cozette, 2008, pp. 34-35). First and foremost citizens identify themselves more with their nation-state than they do with "human race" or with the abstract idea of "international community" (Donnelly, 2000, p. 131; Kortunov, 2006, p. 12). It is vivid that human nature is contrary to the basic principle of Ahimsa, which rejects individual's special closeness and treatment to his or her families, relatives, community, and race.

States are committed to promote their national interests to get acceptance before the international community and institutions through boosting their military, economic, political, ideological, strategic and diplomatic power. They consciously know the value of relative power which determines "what will or will not happen" and "who will get or will lose" in the arena international politics (Kassner, 2007, pp. 30-31).

States are also autonomous actors in international relationships. There is no central authority that employ coercive power to regulate their relations and behaviors. It is characterized by anarchism (Waltz, 1988, p. 619; Doppelt, 1978, pp. 3-5; Donnelly, 2000, pp. 107-120). In an anarchic realm, peace and morality are fragile and uncertain. The situation of international politics, where there is no dominant global authority is similar with the nature of man in state of nature. In Leviathan, Hobbes (1651, pp. 89-90) clarified the analogy:

It may peradventure be thought, there was never such a time, nor condition of war as this, and I believe it was never generally so, over all the world. But there are many places where they live so now. For the savage people in many places of America, except the government of small families, the concord where of depends on natural lust, have no government at all, and live to this day in that brutish manner, as I said before. Howsoever, it may be perceived what manner of life there would be where there were no common power to fear, by the manner of life which men that have formerly lived under a peaceful government use to degenerate into in a civil war. But though there had never been any time wherein particular men were in a condition of war against one another, yet in all times kings and persons of sovereign authority, because of their independence, are in continual jealousies, and in the state and posture of gladiators, having their weapons pointing and their eyes fixed on one another-that is, their forts, garrisons and guns upon the frontiers of their kingdoms, and continual spies on their neighbors, which is a posture of war.

In this context, the prolongation of peace necessarily requires jeopardizing the security and development endeavors of some or all of the system's principal actors (Waltz, 1988, p. 20). National interest of states could be achieved through the effective utilization of both soft power (diplomacy) and hard power (force). If states are 
weak, employing the advantage of balance of power is the only mechanism to defend and maintain their national interests. In the history international relations, states have been using such balances to counter threats and dominance from other powerful states (Donnelly, 2000, pp. 44-85; Bull, 2002, pp. 97-100). In this anarchic international system, in contradiction to the principles and values of Indian tradition of Ahimsa, even weak states do not rely on universal element of love and truth to secure their national interests and priorities. By conducting open deliberations, dialogues, debates, persuasions and non-cooperation with evil actors, sovereign states cannot secure their survival and national interests.

\section{International Laws and Organizations; National Interest Vs Justice, Universal Love and Oneness of Men}

In principle, international laws and organizations are established in line with the moral values and principles of Indian tradition of Ahimsa. They are established to maintain and promote unity, justice, integrity, love, friendship, and equality among sovereign states. In reality, manners and activities of international laws and organizations have been contradictory with the moral principles and values of Ahimsa. They are guided and determined by the logic of national self-interest; less concerned with moral attributes of Ahimsa.

In international relations, the relationship among the sovereign states is regulated by states' calculation of their national interest. International laws and organizations have been instruments of facilitating cooperation among sovereign states (Donnelly, 2000, pp. 131-138, pp. 161-162; Mearsheimer, 1995, p. 9). As long as sovereign states are guided by national priorities, international laws and organizations cannot play an independent, impartial and significant role to regulate their relationships.

Basically, national interest is characterized by materialism, subjectivity, greed and diversity. This has been causing exploitation, violence, injustice and inequality to be prevalent throughout the development of international relation. Consistently, by siding with the interests of powerful states, international laws and organizations have been instruments of consolidating and perpetuating these imbalances (Morgenthau, 1948).

The core problem is, states are the primary actors of international relations. It is a self-help system and sovereign states are governed by the principle of national interest and relative power. Which means they are legitimate to exercise their sovereign power to act independently in international affairs (Bull, 2002, pp. 3-5, pp. 22-24). Sovereign states may respect rules, norms, practices, alliances or cooperative agreements and the decision making procedures of international laws and organizations as much as their national interests and goals are protected and maximized. Irrespective of international laws and organizations, they are autonomous to make alliances or to declare wars to regulate, persuade and protect their conflictual national goals (Donnelly, 2000, p. 44, p. 85; Sanford, 1999, pp. 5-7; Kiersey, 2007). Waltz (1988, p. 324) illustrated:

States continue to co-exist in an anarchic order. Self-help is the principle of action in such an order, and the most important way in which states must help themselves is by providing for their own security. Therefore, in weighing the chances of peace, the first questions to ask are questions about the ends for which states use force and about the strategies and weapons they employ. The chances of peace rise if states can achieve their most important ends without actively using force. War becomes less likely as the costs of war rise in relation to the possible gains.

International laws and organizations are mainly established and organized based on the self-interest of the great powers. By relying their strong economic, ideological, diplomatic and coercive power, and using international laws and organizations as an instruments; powerful nations have been advancing their own national interests (Knox, 2009, pp. 433-436; Slaughter, 2011, p. 26; Holsti, 1985, pp. 16-18).

To promote liberalism that best serves their interest, America and western Europe had created many international institutions and laws, values and standards by which all other systems should be measured. Under the slogan of "development, political and social transformations"; foreign penetration, diffusion, acculturation of values, techniques, and ideas from the centers to the periphery has systematically implemented through international financial and economic institutions. These European values have been implanted to legitimize exploitation, domination and subordination of underdeveloped nations by the capitalist west (Knox, 2009, pp. 433-436; Ramon, 2000, pp. 361-363; Ferraro, 1996, pp. 3-6). Ferraro (1996, p. 3) elaborated:

The capitalist system has enforced a rigid international division of labor which is responsible for the underdevelopment of many areas of the world. The dependent states supply cheap minerals, agricultural commodities, and cheap labor, and also serve as the repositories of surplus capital, obsolescent technologies, and manufactured goods. These functions orient the economies of the dependent states toward the outside: money, goods, and services do flow into dependent states, but 
the allocation of these resources are determined by the economic interests of the dominant states, and not by the economic interests of the dependent state. This division of labor is ultimately the explanation for poverty and there is little question but that capitalism regards the division of labor as a necessary condition for the efficient allocation of resources.

This exploitative relationship has caused under development, poverty, frustration, conflict, violence, hatred, greed and dependence to the third world nations. In this regard, Holsti $(1985$, p. 17) remarked, "[This exploitative nature of] world system not only gives rise to and perpetuates a widening rather than narrowing gap between the wealthy core and poor periphery but also to a dependency relationship from which the latter are unable to break loose".

The above logical arguments make clear, the principles and moral values of Indian tradition of Ahimsa has no genuine and significant role in the implementation of international laws and organizations. Moral notions of international laws and organizations such as the principle of moral duty, justice, equality, brotherhood, and integrity have always been tools of legitimization for the exploitation of domestic politics of peripheral nations.

\section{Conclusion}

In addition to its role to spiritual development and self-realization of individual's soul, Indian tradition of Ahimsa which teaches absolute non-violence and morality is also believed by followers as a means of realizing absolute peace, justice, equality, freedom, oneness and love in the arena of national and international politics.

Practically, the application of principles and moral values of Ahimsa have been insignificant and questionable in the politics of modern states and international relations. The fundamental nature of the politics of modern states and international relations is characterized by the continual existence of contradiction, conflict, collision, disagreement, and competition within and among the sovereign states.

The underlining idea of Ahimsa, absolute morality and non-violence cannot be practical in the internal politics of modern states. Principles and values of Ahimsa are fundamentally contradictory with the definition, function and dynamic nature of modern politics.

1) Modern states are basically established to regulate the competitive, conflictual and complex natures of human beings. Whether they are strong or weak, modern states or governments as a political institution are defined by their monopoly of political power and legitimate use of force.

2) The maintenance of morally right social and institutional values, and the accommodation of divergent social, political, cultural and economic interests are dependent on state's monopolization and effective use of coercive power.

3) In modern society, due to pluralism of ideas, debates, values and judgments; people strongly disagree on what should be the social norms or moral principles. This cause competition and conflict to be inevitable and continual in national politics. Recognizing the natural diversity of human ideas, pluralism is valued as the main principle of democratic system of modern politics. In the politics of modern states, political debates and competitions are on economic arguments, socio-cultural policies, and other logical reasons of state. Morality is only considered as a tool for winning the electorates approval and augmenting political power of the leaders.

Besides of its imagined role to the internal politics of modern states, the tradition of Ahimsa advocates the possibility of economic and political non-cooperation and isolation of India from morally deteriorated external world, particularly from the capitalist West. On the other aspect, Ahimsa urges follower to struggle for the actualization of universal love, truth, equality, justice and humanism on the earth. This is ideal principle of Ahimsa is in contradiction with the real natures of international politics.

1) In contradiction to the principle of Ahimsa, states are rational actors, which are guided by the principle of national interests and priorities. Realistically, national interests of states are defined in terms of securing survival, security, power, ideological beliefs, and material gains; not in terms of universal principles of love, humanity, equality and justice. In international relations, states are not mainly concerned with moral justifications beyond securing their national privileges. Depending on their own relative power, they get in to cooperation primarily calculating the amount of national interest they can gain from the relationships.

2) In anarchic international political system; national interests of states could be achieved through the effective utilization of both soft power (diplomacy) and hard power (force). If states are weak, employing the advantage of balance of power is the only mechanism to defend and maintain their national interests. Even weak states do not rely on universal element of love, faith, oneness and truth to secure their national interests and priorities. By following Ahimsa's principle of conducting an open deliberations, dialogues, debates, persuasions and 
non-cooperation with competitors and evil actors, sovereign states cannot secure and satisfy their national interests.

\section{References}

Bhaneja, B. (2007). Understanding Gandhi's Ahimsa (Non-Violence): Reflection on an Autobiography, the Story of My Experiments with Truth. Resen has Book reviews. Retrieved from https://www.nightslantern.ca/gandhiasteriskos.pdf

Bishop, P. (1978). Ahimsa and Satyagraha: An Interaction of Hindu and Christian Religious Ideas, and Their Contribution to a Political Campaign. Department of Brighton Polytechnic, England. Retrieved from https://www.biblicalstudies.org.uk/pdf/ijt/27-2_053.pdf

Bodewitz, H. (1999). Violence Denied: Violence, Non-Violence and the Rationalization of Violence in South Asian Cultural History. Brill Academy.

Bull, H. (2002). The Anarchical Society: A Study of Order in World Politics. Palgrave Hound mills, Basingstoke, Hampshire RG21 6XS and 175 Fifth Avenue, New York.

Chen, F. (2010). Civilization and Competition: Study Societies and State Formation in Late Qing China Hon. Yan University, Hong Kong.

Cozette, M. (2008). Raymond Aron and the Morality of Realism. Department of International Relations, Australia National University of Canberra, Australia.

Donnelly, J. (2000). Realism and International Relations. England: Cambridge University Press. https://doi.org/10.1017/CBO9780511612510

Dopplet, G. (1978). Waltz's Theory of Morality in International Relations: Philosophy and Public Affairs. Princeton University Press, USA.

Edwards, P. (1958). Hard and Soft Determinism: Indeterminism and Freedom in the Ages of Modern Science (H. Sidney, Ed.). New York City: New York University Press.

Ferraro, V. (1996). Dependency Theory: An Introduction. Mount Holyoke College, USA.

Flood, G. D. (1996). An Introduction to Hinduism. England: Cambridge University Press.

Gandhi, M. (1948). An Autobiography or the Story of My Experiments with Truth. Navajivan Publishing House, India.

Godrej, F. (2011). Gandhi's Corporeal Non-Violence: Ascetics, Warriors, and Ecological Citizenship. University of California, California.

Gregg, R. (1981). The Power of Non-violence. Primer of Company on Planting.

Hobbes, T. (1651). Leviathan (M. Oakeshott, Ed.). Blackwell (1946), Oxford.

Holsti, R. (2005). Theories of international Relation. Retrieved from https://people .duke.edu/pfeaver/holsti.pdf

Kassner, J. (2007). Rwanda and the Moral Obligation of Humanitarian Intervention. Faculty of the Graduate School of the University of Maryland, college park, in Partial Fulfilment of the Requirements for the Degree of Philosophy. Retrieved from https:/drum.lib.umd.edu/bit stream/1903/6844/1/umi-4333.pdf

Kiersey, N. (2007). Power and International Relations Theory: Why the Debate about Empire matters? Blacksburg Publishing Centers, Virginia.

Knox, R. (2009, July 29). Marxism, International Law and Political Strategy. Leiden Journal of International Law, 22, 413. https://doi.org/10.1017/S0922156509990021

Kortunov, A. (2006). Realism and Morality in Politics. Academy of sciences of USSR, Institute of USA and Canada Studies, USSR.

Kovan, M. (2009). Violence and Non-resistance: Buddhist Ahimsā and its Existential Aporias. Journal of Buddhist Ethics, 16. Retrieved from https://http://www.buddhistethics.org

Krishna, K. (1969). All Men Are Brothers, Life and Thoughts of Mahatma Gandhi: As Told in His Own Words. United Nations Educational, Scientific and Cultural Organization, Presses Centrales Lausanne S.A.

Kumar, S. (1997). Buddha as Depicted in the Purāṇas. In Encyclopedia of Hinduism (pp. 260-275). Anmol Publications. 
Kurtz, L., \& Kurtz. (2005). Solving the Qur'anic Paradox. Retrieved from https://http://works.bepress.com/Lester_Kurtz/10

Larmore, C. (2012). What is Political Philosophy? Journal of Moral Philosophy.

Lipson, L. (2005). Morality and Political Discourse. Retrieved from https://yanpeichen.com/professional/morality and political discourse .pdf

Machiavelli, N. (1532). The prince (W. K. Marriott, Trans.). Falbe Publishing of Chicago, USA.

Mahony, W. K. (1987). Perspectives on Krishna's Various Personalities. Journal of History of Religions, American Oriental Society, 26(3), 333-335. https://doi.org/10.1086/463085

Marcel, P. (2011). Fragmenting Mexico's Leviathan: The Coercive Apparatus and the Dirty war in Guerrero under Luis Echeverrsa's Administration (1970-1776). Columbia University of Graduate School of Arts and Sciences, Master of Arts in regional studies, Latin America and Caribbean.

Mearsheimer, J. (1995). The False Promise of International Institutions. President and Fellows of Harvard College and Massachusetts of Technology, USA.

Michael, M. (2011). Monopoly of Force: The Nexus of DDR and SSR. Center for Complex Operations, Institute for National Strategic Studies, National Defense University Press, Washington DC.

Miller, J. (1984). Questions That Matters: An Invitation to Philosophy. Mc GRAW- Hill Book Company, USA.

Morgenthau, H. (1948). Politics among Nations: The Struggle for Power and Peace. Alfred A. knop, Inc, Chicago University, USA.

Namita, N. (2008). Satyagraha as the Gandian Solution to Resolve Conflict. Retrieved from https://www.vpmthane.org

Prana, S. (2003). Ahimsa: The Practice of Non-Violence. Griffith University, Brisbane, Australia.

Ramon, N. (2000). Developmentalism, Modernity and Dependency Theory in Latin America: Views from South (Vol. 1). Duke University Press.

Rawls, J. (2001). Four Roles of Political Philosophy. USA: Harvard University Press.

Rotberg, R. (2003). When States Fail: Causes and Consequences. USA: Princeton University Press.

Sanford, J. (1999). International Organizations as Instruments of Foreign policy. National Defense Library, Washington, DC.

Sharma, I. (1965). Ethical Philosophy of India. Nebrastra Johnson Publishing Company, University of Kebangsaan, Malaysia.

Sihra, K. (2006). Philosophical Contributions of Gandhi's Ideas on Non-Violence: Research and Practice in Social Sciences (Vol. 2, No. 1). Ontario Institute for Studies in Education, University of Toronto, Canada.

Slaughter, M. (2011). International Relations: Principal Theories. England: Oxford University Press.

Strauss, L. (1959). What is political Philosophy? University of Chicago Press, Ltd. USA.

Waltz, K. (1988). The Origins of War in Neo-Realist Theory: The Origin and Prevention of Major Wars. USA: MIT Press.

William, S. (2001, November). African Armed forces and The Challenges of Security Sector Transformation. Strategic Review of Southern Africa, 23(2), 1-34.

\section{Notes}

Note 1. Principles of Ahimsa are guidelines that regulate actions, manners behaviors of follower in their daily life. These principles are means for followers to be absolutely non-violent and morally perfect. Basic principles are; principle of searching and dying for the truth, non-possession of material property, accepting equality, complete self-purification of soul, hating the sin and not the sinner, and the principle of civil disobedience, protest, persuasion and non-cooperation with evil doers (Namita, 2008; Godrej, 2011; Bhaneja, 2007; Prana, 2003; Kurtz \& Kurtz, 2005).

Note 2. Mahatma Gandhi (2 October 1869-30 January 1948), the first president of independent India, was the preeminent leader of the Indian independence movement in British-ruled India. Employing nonviolent civil disobedience, Gandhi led India to independence and inspired movements for civil rights and freedom across the 
world. Gandhi believed that there was no other God than Truth, and that the only means for realization of Truth was Ahimsa. Truth to Gandhi was synonymous with God. He also struggled to address socio economic upheavals of India; for the purposes of Hindu-Muslim unity, abolition of caste based untouchability, and advocacy of home-spun Swadeshi clothing (Bhaneja, 2007; Krishna, 1969).

Note 3. Ahimsa is consists of many moral values or attributes. Some of fundamental moral values are; Universal love, compassion, patience, civility, chastity, humility, simplicity, godliness, tolerance, freedom, happiness, wisdom, confession, integrity, courage, charity, eternity, equality, self-purification, self-actualization, and spiritualism (Prana, 2003; Bhaneja, 2007; Gregg, 1981).

Note 4. Krishna is one of the most widely revered and popular of all Hindu deities, traced to as early as the 4th century BC. Krishna's birthday is celebrated every year by Hindus. It is recognized as the complete and or as the Supreme God in his own right; and worshipped across many traditions of religion in a variety of different perspectives. The story of Krishna appears across a broad spectrum of Hindu philosophical and theological traditions. They portray him in various perspectives: a god-child, a prankster, a model lover, a divine hero, and the Supreme. It is often described and portrayed as an infant eating butter, a young boy playing a flute, and surrounded by beautiful women (Mahony, 1987).

Note 5. Sanatana Dharma is the original name of what is now popularly called Hinduism or Hindu Dharma. The terms Hindu and Hinduism are said to be a more recent development, while the more accurate term is Sanatana Dharma. It is a code of ethics, a way of living through which one may achieve moksha (enlightenment, liberation). It is the world's most ancient culture, socio-spiritual, and religious tradition of almost one billion of the earth's inhabitants. Sanatana Dharma represents much more than just a religion; rather, it provides its followers with an entire worldview, way of life and with a coherent and rational view of reality (Flood, 1996).

Note 6. Buddha (c. 600 BCE-c. 300 BCE) was a spiritual leader and teacher whose life serves as the foundation of the Buddhist religion. Siddhartha Gautama, who would one day become known as Buddha ("enlightened one" or "the awakened"), lived in Nepal during the 6th to 4th century B.C. While scholars agree that he did in fact live, the events of his life are still debated. According to the most widely known story of his life, after experimenting with different teachings for years, and finding none of them acceptable, Gautama spent a fateful night in deep meditation. During his meditation, all of the answers he had been seeking became clear, and achieved full awareness, there he became Buddha (Kumar, 1997).

Note 7. The dialectical law of nature shows that the two contradictory realities, thesis and antithesis are the governing principles of change throughout the development of human history. The apparent contradictions between thesis and antithesis have been resolved by making mutual compatibility or synthesis. The synthesis created by combination then becomes new thesis and for this thesis there has been antithesis (Shimp, 2009). Which means, as Miller (1984) stated "Nothing appears pure in and by itself, but only combination with [it's opposite]; air, light, moisture, solidity, heat, cold, movement, exhalations, [bad and good], and other forces...between light and heavy, strong and weak, greater and less, up and down". As part of nature, human beings are also governed by this immutable law. They cannot be absolutely bad or god; and violent or non-violent.

\section{Copyrights}

Copyright for this article is retained by the author(s), with first publication rights granted to the journal.

This is an open-access article distributed under the terms and conditions of the Creative Commons Attribution license (http://creativecommons.org/licenses/by/4.0/). 